УДК 94(4) “192/199” В. Комар

\title{
МОЛОДІЖНА ПОЛІТИКА В САНАЦІЙНІЙ ПОЛЬЩІ 1930-х років
}

\author{
Володимир КОМАР \\ ДВНЗ “Прикарпатський національний університет імені Василя Стефаника" \\ кафедра історії слов'ян \\ вул. Шевченка, 57, Івано-Франківськ, 76025, Україна \\ e-mail: wolodymyr.komar@gmail.com
}

\begin{abstract}
Проаналізовано формування молодіжної політики в контексті реалізації концепції прометеїзму міжвоєнної Польщі. Ці ідеї поділяли соратники Ю. Пілсудського, згруповані в товаристві “Прометей” й так званому прометеївському русі. Антиросійська й антикомуністична спрямованість концепції була скерована на розпад Радянського Союзу й побудову на його національних окраїнах незалежних держав, об'єднаних у федерацію з Польщею. Польській і емігрантській молоді в Польщі відводилася ключова роль реалізувати цю політику.

Ключові слова: Ю. Пілсудський, Т. Голувко, В. Бончковський, прометеїзм, Східний інститут.
\end{abstract}

Концепція прометеїзму Польщі стала актуальною після травневого перевороту 1926 р. іприходу до влади режиму санації. Своїм зовнішньополітичним вектором вона була спрямована на розпад Радянського Союзу з перспективою утворення незалежних держав під егідою Польщі. Будучи переконаними у недовговічності існування багатонаціональної радянської імперії нового типу, прихильники прометеїзму з табору Ю. Пілсудського прагнули залучити в орбіту своїх політичних впливів неросійські народи, створюючи окремі національні держави на просторі від Балтійського до Чорного морів (України, Грузії, Азербайджану, Криму та інших) і підпорядкувати їх Польщі на основі федераційних зв'язків. Для реалізації цієї концепції було необхідно виховати молодь і не лише польську, а й з еміграційного середовища. Провідну роль мав відігравати Східний Інститут (CI). В його діяльності головну роль відводилося українському питанню, що підкреслює актуальність обраної теми для вітчизняної політики й науки.

Дороговказом у вихованні молоді стали слова Ю. Пілсудського, якому польський народ завдячував своїм державницьким існуванням: “Праця для блага вітчизни - це наша мета і обов'язок!”'. Окрилена словами Ю. Пілсудського, польська молодь виношувала плани боротьби 3 радянською тоталітарною системою. Для молоді життя Ю. Пілсудського було орієнтиром для наслідування. Окрім того, націоналізм Ю. Пілсудського вирізнявся реалізмом. Він відкидав всілякі партійні інтереси, всілякі непотрібні дискусії про соціяльні принципи, які розпорошували сили, а концентрував зусилля в одному напрямку. Сприйняття

\footnotetext{
${ }^{1}$ Centralne Archiwum Wojskowe (CAW), Oddział II Sztabu Głównego (Od. II Sz. G1.), sygn. I.303.4.5554, k.22 (Orijentalistycznå Koło Młodych. Hasło "Wasza Wolność - Nasza Potęga”).

(C) Комар В., 2018 
політичного реалізму Ю. Пілсудського сприяло також налагодженню конструктивного діялогу між старшим прометеївським поколінням і молоддю та створювало умови для взаємної співпраці. Велику надію покладалося насамперед на польську молодь, а також на молоду генерацію в середовищі емігрантів з Росії, особливо українців ${ }^{2}$. Вони мали спільно з поляками працювати, щоб відродити Велику Польщу, яка була кінцевою метою в реалізації концепції прометеїзму.

Значна виховна робота в молодіжному середовищі проводилася на базі Східного Інституту. Восени 1928 р. керівництво СI за дорученням Експозитури № 2 Відділу II Головного штабу Війська Польського активно намагалося залучити до своєї діяльности польську молодь, передусім зі студентських організацій “Легіон Млодих" (“Legion Młodych”) і “Союзу польської демократичної молоді”з (“Związek Polskiej Młodzierzy Demokratycznej”). Так поступово визріла ідея створити молодіжну організацію, діяльність якої носила б науково-дослідний характер й була спрямована вивчати проблеми Сходу в широкому значенні цього слова. Цю ідею у кінці 1928 р. сформулював В. Пельц, який був студентом Варшавського університету й членом колегії секретарів Східного Інституту (CI), який вважався “мозковим центром” прометеїзму. Генеральний секретар інституту С. Корвін-Павловський підтримав цю ініціятиву ${ }^{4}$.

Відтак 5 грудня 1928 р. відбулися установчі збори організаційного комітету, на яких ухвалили створити молодіжне товариство під назвою “Академічний Орієнтальний Гурток”. Однак вона не прижилася, й тому 17 квітня 1929 р. гурток перейменували на Орієнтальний Гурток Молоді (ОГМ) при СІ у Варшаві5.

Першим головою ОГМ став В. Бончковський, який одночасно був редактором квартальника "Wschód”. До складу правління ОГМ у 1931 p. входили: голова - В. Бончковський (залишався до 1939 р.), заступник К. Імнадзе (одночасно очолював Грузинський комітет у Польщі), секретар М. Бродзіковська, скарбник - В. Хмєлевська, члени - Р. Курніцький, М. Ліннер, 3. Пешке, Б. Дембінський. Окрім того, активними діячами ОГМ були В. Пельц і К. Сейфрід ${ }^{6}$. Новостворена молодіжна організація постійно розширювалася й незабаром налічувала вже понад 100 активних учасників. Згідно зі статутом ОГМ з членів правління СІ вибирався куратор, який контролював його діяльність. Першим цю функцію виконував тогочасний генеральний секретар Східного Інституту С. Корвін-Павловський. Згодом кураторами були інші відомі державні

${ }^{2}$ Centralne Archiwum Wojskowe (CAW), Oddział II Sztabu Głównego (Od. II Sz. Gł.), sygn. I.303.4.5693, k.28 (L. Uwagi o kwestii reorganizacji pracy prometeuszowskiej w Paryżu.1936).

${ }^{3}$ Ibid., I.303.4.5701, k.1 (O.K.M. przy Instytucie Wschodnim w Warszawie).

${ }^{4}$ Ibid., sygn. I.303.4.5516, k.5 (OKM przy Instytucie Wschodnim w Warszawie - charakterystyka, 2.III.1931).

${ }^{5}$ Ibid., sygn. I.303.4.5554, k.7 (Rzut oka na historję O.K.M.).

${ }^{6}$ Ibid., k.2 (Orijentalistycznå Koło Młodych. IV.1931 r.). 
ISSN 2078-6077. Наукові зошити історичного факультету Львівського університету. 2018-2019. Випуск 19-20. Proceedings of History Faculty of Lviv University. 2018-2019. Issue 19-20.

діячі Польщі: В. Дриммер - начальник персонального відділу МЗС, капітан Е. Харашкевич - начальник Експозитури № 2 Відділу II ГШ, а від листопада 1932 р. - А. Кавалковський - радник Міністерства релігійних визнань і освіти (МРВ і О), який високо оцінював діяльність ОГМ у плані її співпраці з молоддю народів СРСР, а також Близького і Далекого Сходу․

Щоб реалізувати поставлені завдання, керівництво ОГМ опиралося на підтримку офіційних урядових чинників, зокрема Відділу II ГШ, участь якого в діяльності й фінансуванні товариства була законспірована.

Перед ОГМ стояли завдання: поширювати антирадянську пропаганду та прометеївську ідеологію в середовищі польської та еміграційної молоді в Польщі й за кордоном; досліджувати суспільно-політичні відносини в Радянському Союзі; налагоджувати контакти 3 молодіжними організувати інших країн; організація пропагандистські подорожі та екскурсій

Робота ОГМ проводилася в секціях. Ідеологічна займалася формуванням світогляду молоді в руслі концепції прометеїзму. Кавказька секція утворена в 1930 р. і об'єднала в собі польську молодь з молодіжною еміграцією з Кавказу і Закавказзя9. Ї̈і очолив М. Чукуя. Українська секція започаткована у Львові в 1932 р. з метою інформувати польське суспільство про прометеївську діяльність української еміграції, а також створити умови для налагодження польськоукраїнської співпраці. Її очолив К. Симонолевич ${ }^{10}$. Кримсько-Ідель-Уральська секція виникла в листопаді 1934 р. $з$ метою налагодити співпрацю між польською молоддю та іiї ровесниками в середовищі татарської еміграції. Секція Близького Сходу вирішувала завдання політичної й економічної співпраці з місцевими народами. Для цього проводили екскурсії членів ОГМ. Радянологічна секція під керівництвом М. Яцулевича розпочала роботу на початку 1932 р. Її завдання дослідити суспільно-політичні, економічні і культурні відносини в СРСР ${ }^{11}$. Пропагандистсько-видавнича секція займалася агітаційними акціями й поширювала прометеївську ідеологію, видаючи часопис "Wschód" ${ }^{12}$. Секція Далекого Сходу інформувала членів ОГМ про політичне, економічне й культурне життя емігрантів з СРСР у цьому регіоні.

Відділення ОГМ були організовані в Кракові, Львові, Вільно, Познані, а філії в Парижі та Празі. Зокрема, для паризької філії, яка розпочала роботу 1932 р.,

\footnotetext{
${ }^{7}$ BPP, AAK, sygn. 1156/I, k.72 (Notatka dla Pana Ministra Jędrzejewicza "Nastroje polityczne młodzieży akademickiej”).

${ }^{8}$ Российский государственный военный архив (РГВА), ф.461/к, оп.1, д.1, л.161 (Orjentalistyczne Koło Młodych przy Instytucie Wschodnim w Warszawie).

9 “Z życia Orjentalistycznego Koła Młodych", Wschód-Orient, 1930, nr 1, s. 31.

10 “Z życia Orjentalistycznego Koła Młodych w Warszawie", Wschód-Orient, Październik 1932 maj 1933, R.IV, nr 1-2 (9-10), s. 99.

11 "Z życia Orjentalistycznego Koła Młodych w Warszawie" , Wschód-Orient, Styczeń 1932, r. III, nr 1-2 (5-6), s. 90.

${ }^{12}$ CAW, Od. II Sz. Gł., sygn. I.303.4.5554, k.7 (Rzut oka na historję O.K.M.).
} 
виділялася дотація у розмірі 500 франків на місяць. Для роботи ОГМ у Варшаві розміри субвенцій складали 450 зл. Водночас проводилася організаційна робота - створення філій інших польських університетських містах, а також за кордоном.

Серед закордонних відділів активністю вирізнялась Харбінська філія ОГМ. Їй підпорядковано “Студентський гурток дослідження Китаю” в Харбіні, який у 1931 р. змінив назву на "Польський сходознавчий гурток”. Робота ОГМ у Харбіні пожвавилася з приїздом туди В. Пельца. Він, як делегат "Польсько-китайського товариства”, поїхав на Далекий Схід за дорученням Т. Голувка для пропаганди ідей прометеїзму серед місцевих емігрантів з Росії. У 1932 р. головою правління ОГМ в Харбіні був інженер К. Гроховський, секретарем - А. Лижва, заступниками - Л. Влецял і Г. Садковський, скарбником - В. Копалінський. В. Пельц у списках товариства значився рядовим членом, однак, як свідчать документи, йому відводили головну роль у реалізації прометеївської акції на Далекому Сході. Консул Польщі в Харбіні А. Квятковський (у документах виступав під псевдонімом “Cholski”.) був посередником між ОГМ та Експозитурою № 2. Пропагували прометеїзм на сторінках часопису "Daleki Wschód” (“Далекий Схід”), який був створений на базі газети "Listy Charbińskie" (“Харбінські листи”). Додатком до тих газет були молодіжне видання. Фінансували прометеївські друки на Далекому Сході з бюджету Експозитури № 2, воно складало 450 зл. ${ }^{13}$.

Ідейним гаслом організованої в ОГМ молоді стали слова: “Ваша свобода наша могутність!”, яке лунало на міжнародних прометеївських форумах. 15-16 травня 1932 р. відбувся Перший конгрес делегатів ОГМ, матеріяли якого були опубліковані в останньому номер часопису "Wschód" за серпень - вересень 1932 р. під назвою “Перший з'їзд Орієнтальних гуртків молоді”"14. Головував на 3'їзді В. Бончковський ${ }^{15}$. Сюди прибули молодіжні делегації ОГМ з Вільна, Кракова, Львова, Познані та інших міст. Польська молодь засвідчила приязнь до азербайджанців, грузинів, татар і українців та висловилася за співпрацю 3 ними.

Відтак 22 грудня 1933 р. в Римі відбувся Конгрес молоді за участю майже 700 представників з Японії, Маньчжурії, Монголії, Китаю, Туреччини, Індії та Персії. Конгрес урочисто відкрив політичний діяч, фашистський диктатор і прем’єр-міністр Італії Беніто Муссоліні. Це був перший конгрес молодого Прометея Азії ${ }^{16}$.

${ }^{13}$ CAW, Od. II Sz. G1., sygn. I.303.4.5701, k.2 (O.K.M. przy Instytucie Wschodnim w Warszawie).

${ }^{14}$ Ibid., k.1zw. (Deklaracja O.K.M. - odpowiedź na depesze MARTINA. 17.VIII.1932 r.).

${ }^{15}$ CAW, Od. II Sz. Gł., sygn.I.303.4.5554, k.2 (Prezydium Pierwszego zjazdu Orijentalistycznych Kół Młodych w Warszawie. 3.VIII.1932 r.).

${ }^{16}$ Ibid., sygn. I.303.4.5782, k.627 ("Prometeusz" - Liga uciemieżonych przez Rosje narodów: Azerbajdżan, Don, Kubań, Gruzja, Idel-Urał, Ingria, Karelia, Komi, Krym, Kaukaz Pólnocny, Turkiestan i Ukraina. Komunikat ${ }^{1} 1$, styczeń 1934 r.). 
ISSN 2078-6077. Наукові зошити історичного факультету Львівського університету. 2018-2019. Випуск 19-20. Proceedings of History Faculty of Lviv University. 2018-2019. Issue 19-20.

У рамках ОГМ при Східному інституті протягом кількох років на канікулах організововано екскурсії молоді до Румунії, Болгарії, Югославії, Туреччини, Єгипту й країн Близького Сходу ${ }^{17}$. Мета подорожей - налагодити співпрацю 3 місцевими студентськими організаціями. У 1934 р., зокрема, відбулися екскурсії до Туреччини, а в 1935 р. - до Румунії. Маршрут подорожі був таким: Варшава Бухарест - Софія - Варна - Стамбул - Констанца - Бухарест - Львів Варшава ${ }^{18}$. У 1936 р. 25 студентів з ОГМ виїхало з екскурсією до Румунії, Болгарії й Туреччини. Начальник Експозитури № 2 майор Е. Харашкевич всіляко підтримував почини молоді. Він, зокрема, звертався з проханням до міністра зв'язку полковника Ульріха надати знижки в придбанні білетів студентам на час подорожі. Натомість Відділ національностей МВС мав забезпечити виготовлення закордонних паспортів. Так на високому державному рівні підтримували студентів-прометеїстів, що свідчило про важливість цієї справи для східної політики Польської держави.

Про діяльність ОГМ із журналу “Wschód” довідалися представники російської білогвардійської еміграції. Їх обурило, що в основу зближення народів Близького й Далекого Сходу була покладена специфічна пропаганда розпаду й знищення Росії. Увагу автора статті привернула “Карта поневолених народів Росії, яку вміщено в журналі. Від великої Росії на ній залишався лише трикутник території, один кінець якого упирався в Фінську затоку, другий у Воронезьку губернію, а третій - в Карське море. На решті території колишньої Російської імперії були зображені нові держави: Україна, Білорусь (хоча й без своїх етнічних земель, які знаходилися в складі Польщі); козацькі землі, Крим, Карелія - від Ладоги до Льодовитого океану, Ідель-Урал, Зирянія; держава Сибірія, яка на карті виглядала в три рази більшою від Росії; Якутія і Туркестан, які дорівнювали Сибіру; Бурятія і Далекий Схід - від Маньчжурії до Аляски. 3 чотирьох сторін карти польською і англійською мовою було написано "Росія - це тюрма народів", "Майбутнє - це розпад Росії на окремі національні держави", що найбільше обурило автора статті. Він протестував проти того, що ставився знак рівности між Росією дореволюційною і радянською, між російським народом i більшовиками. Російський емігрант вважав пропаганду таких ідей фатальною помилкою для Польщі ${ }^{19}$.

Залучали молодих емігрантів до участи в прометеївському русі не лише безпосередньо в Східному Інституті й ОГМ, а й надаючи стипендії для навчання у польських і закордонних університетах. 3 цією метою був створений спеціяльний фонд імени Т. Голувка, з якого призначалися стипендії українським студентам, що навчалися у Варшавському університеті, передусім на

\footnotetext{
${ }^{17}$ CAW, Od. II Sz. G1., sygn. I.303.4.5701, k. 1zw. (Wycieczka naukowa Członków O.K.M. przy Instytucie Wschodnim w lecie 1936 r. na Bliski Wschód. 15.VII.1936 r.).

${ }^{18}$ Ibid., k.1 (Wycieczka O.K.Mu. do Bułgarii w czasie od 3.VIII. do 30.VIII.1936 r.).

${ }^{19}$ В. Абданк-Коссовский, “Чудский передел Россіи”, Возрождение, №2592, (1932), с. 2.
} 
гуманітарному і юридичному факультетах ${ }^{20}$. Стипендії надавали насамперед особам, які були ознайомлені з життєвим шляхом та ідеологічними переконаннями Т. Голувка. Подання на призначення стипендії адресували секретареві кураторії професорові Варшавського університету Р. Смаль-Стоцькому ${ }^{21}$.

Значну увагу в діяльності УНІ приділяли вихованню молоді. 3 цією метою частину коштів, що надходили з фондів МРВ і О, керівництво інституту перерозподіляло на стипендії для петлюрівської молоді, яка мала перейняти традиції старшого покоління. За даними на січень 1935 р., з фонду УНІ одержували стипендії такі студенти: А. Крижанівський - 175 зл.; П. Холодний (молодший), Г. Лазаревський, Є. Маланюк, М. Рогозінський, П. Васинчук всі по 150 зл.; М. Куніцький - 50 зл.; Ян Сойко 25 зл.. Разом на студентівукраїнців виділено сума 1 тис. зл. ${ }^{22}$. А. Крижановський був секретарем лінгвістичної секції Комісії з досліджень польсько-українських проблем й секретарем Комісії історії літератури. П. Холодний (молодший) закінчив у 1934 р. відділення живопису Академії мистецтв у Варшаві й продовжив студіювати графіку в тому ж навчальному закладі. П. Крижанівський у Східному Інституті вивчав турецьку, арабську й болгарську мови та готувався до вступу в Університет імени Ю. Пілсудського у Варшаві. Г. Лазаревський був співробітником УНІ. М. Рогодзінський, ставши магістром філософії після закінчення Університету імені Ю. Пілсудського, виконував обов'язки асистента професора М. Кордуби й писав кандидатську дисертацію на катедрі української історії в тому ж університеті. П. Васинчук у 1934 р. закінчив факультет права і суспільних наук Люблінського університету. М. Куніцький виконував технічну роботу в комісії з видання повного зібрання творів Т. Шевченка, яка працювала в УНІ. Ян Сойко навчався під керівництвом професора О. Лотоцького на четвертому курсі православного теологічного відділуУніверситету імени Ю. Пілсудського.

Окрім того, діти емігрантів безкоштовно вчилися в інших польських вишах. У 1934-1935 н. р. одержували стипендії з прометеївських фондів для навчання в Академії мистецтв, Школі політичних наук, Варшавському університеті, Варшавській політехніці: п'ятеро азербайджанців, троє грузинів, троє північнокавказців, четверо татар, двоє українців (П. Рогодзінський, П. Холодний), десятеро білорусів. У 1935-1936 н. р. навчалися в польських університетах і одержували стипендії: двоє представників татарської еміграції, двоє грузинів, четверо азербайджанців, один емігрант з Північного Кавказу, один

${ }^{20}$ BPP, AAK, sygn. 1136, k.55 zw. (Wypis z aktu notarialnego powołującego Fundacje stypendialną im. Śp. Tadeusza Hołówki).

${ }^{21}$ Центральний державний архів вищих органів влади і управління України (ЦДАВО України), ф.3532, оп.1, спр.11, арк.6 (Листування студентів інституту зі стипендіальним комітетом ім. Головка у Варшаві про виділення стипендій студентам інституту. 28.10.1937-28.12.1938рр.).

${ }^{22}$ CAW, Od. II Sz. Gł., sygn. I.303.4.5507, k.4 (Podział stypendijów ukraińskich w r. 1934-1935 przez Ukr. Inst. Nauk. 11.II.1935 r.). 
ISSN 2078-6077. Наукові зошити історичного факультету Львівського університету. 2018-2019. Випуск 19-20. Proceedings of History Faculty of Lviv University. 2018-2019. Issue 19-20.

білорус і один поляк із-за кордону (Ф. Ібянський - студент Університету ім. Ю. Пілсудського). Східний Інститут виплачував на утримання студентів 1 тис. зл. на рік ${ }^{23}$.

В архівних документах знаходяться характеристики стипендіятів, які навчалися за польські гроші. Серед них нерідко траплялися випадкові люди. Їх скерували туди родичі або знайомі, які були заангажовані у співпраці з поляками і могли дати їм рекомендацію. Зокрема, таким правом користувався лідер туркестанської еміграції - М. Чокаєв. Він традиційно рекомендував молодих людей з Туркестану навчатись в Польщі ${ }^{24}$. Значну роботу в цьому напрямку проводив лідер кримських татар Д. Сейдамет і поволзьких татар А. Ісхакі, які рекомендували навчатися своїх земляків ${ }^{25}$. Після зарахування в студенти за їх долею уважно спостерігали в Експозитурі № 2. В одній із характеристик азербайджанських студентів, яку написав В. Бончковський, читаємо: “Типовий дармоїд, баласт і непотріб”26. Інший, що репрезентував північнокавказьку еміграцію, похваляючись особистим знайомством 3 Т. Голувком, домагався посади заступника голови ОГМ, а не одержавши іï, задовольнявся тим, що позичав гроші у своїх колег й не повертав. У його характеристиці зазначалося: "Баласт на відтинку прометеївськім, алкоголік і злодій"27. Зрозуміло, що поряд з ідейними борцями за свободу поневолених народів у прометеївському русі опинилося чимало й таких, які шукали матеріяльної вигоди або просто виживали - використовували будь-яку можливість покинути СРСР, а потім пристосовувалися до складних умов життя в еміграції. Керівники Експозитури № 2 розуміли ситуацію й намагалися не зважати на це, щоб не відштовхнути від себе решту емігрантів.

Надаючи стипендії, керівництво Експозитури № 2 керувалося також і чисто людськими мотивами. Вони намагалися підтримати в еміграції сім'ї своїх союзників, які потребували допомоги. У зв'язку з важким матеріяльним становищем Н. Жорданії, без його відома керівництво Експозитури № 2 призначило стипендію його доньці Нателлі у розмірі 120 зл. ${ }^{28}$. Українець П. Холодний навчався у Академії Мистецтв ${ }^{29}$. Стипендію він отримав завдяки

\footnotetext{
${ }^{23}$ CAW, Od. II Sz. Gł., sygn. I.303.4.5405 (Korespondencja w sprawie przyznawania stypendijów, kwestionariusze stypendystów narodowośći tatarskiej tatarskiej, 1927-1937).

${ }^{24}$ Ibid., sygn. I.303.4.5502, k.16 (Stypendisci Turkiestańczycy. 4 listopada 1936 r.).

${ }^{25}$ Ibid., sygn. I.303.4.5405, k.17 (Przyjęcie stypendysty-studenta od r.1934-1935). Ibid., k. 25 (Stypendysta Idel-uralski. 1.X.1937 r.).

${ }^{26}$ Ibid., sygn. I.303.4.5772, k.42 (Stypendysci azerbejdźańcy - postępy w nauce i ocena wartości ideowej. 1932 r.).

${ }^{27}$ Ibid., sygn.I.303.4.5571, k.2 (Stypendysci Górale Kaukascy).

${ }^{28}$ Ibid., sygn. I.303.4.5672, k.20 (Stypendium studenckie Natalii Zordanii na studiach w Paryżu. 12.IV.1937 r.); Ibid., sygn. I.303.4.5668, k.12 (Informacja o rozliczenia stypendiow przeslany przez placuwke "Milton" w Paryzu. 1937 r.).

${ }^{29}$ Ibid., sygn. I.303.4.5571, k.47 (P. Wice Dyrektor Departamentu Politycznego i Naczelnik Wydziału Wschodniego MSZ ).
} 
своєму батькові, минуле якого було пов'язане з УНР². Ця турбота пізніше окупалася сторицею, бо виростало молоде покоління людей, які проявили себе в антирадянській боротьбі.

Значну роботу провадило правління організації “Прометей”, щоб залучати організовану студентську молодь в Польщі, зокрема українську. Тут діяла філія української студентської корпорації “Запороже”, яку утворено ще в 1906 р. в Чернівцях. Керівництво Експозитури № 2 намагалося впливати на українських студентів способом підпорядкування собі корпорації “Запороже”. Перші кроки в тому напрямку зроблено 1930 р. 3 нагоди виставки корпорації “Запороже” у Варшаві в помешканні керівника Експозитури № 2 капітана Е. Харашкевича відбулася ознайомча зустріч 3 одним 3 лідерів товариства - Володимиром Ігнатовичем, який був студентом медичного факультету Варшавського університету ${ }^{31}$. Функціонування корпорації “Запороже” в структурі прометеївського руху $з$ українського боку підтримували В. Ігнатович $\mathrm{i}$ $€$. Маланюк. ОГМ у Львові проголосило своїм першорядним завданням налагодити польсько-українську співпрацю ${ }^{32}$.

Наприкінці 1933 р. у Варшаві почали видавати літературний квартальник "Ми" "33. Головним його редактором став А. Крижанівський - син колишнього міністра фінансів уряду УНР, студент Познанського університету, колишній член уряду корпорації “Запороже”, співпрацівник УНІ у Варшаві. Навколо цього квартальника, який ідеологічно стояв на платформі УНР, поступово почала збиратися українська студентська молодь. У своїй діяльності вони опиралася на підтримку старшого покоління діячів УНР. За протекією Р. Смаль-Стоцького на початку 1937 р. для фінансування цієї групи з фондів МВС виділено 1 тис. зл. Відтак 22 січня 1938 р. група "Ми” оформилася в нову націоналістичну групу на платформі ідеології УНР. Його мав очолити доктор медицини Ю. Липа. 3 легкої руки ідеолога українського націоналізму Д. Донцова група Ю. Липи була названа “молодими націоналістами". Вони старалися залучити до свого середовища переважно українських студентів і молодих журналістів, що мешкали у Варшавi ${ }^{34}$. До найвидатніших діячів цієї групи належали: Ю. Липа, А. Крижанівський, Б. Ольховський (псевдонім - “Гучванович”).

Створення нового молодіжного осередку викликало занепокоїло "Українську студентську громаду” у Варшаві. Ї̈і члени ухвалили резолюцію, в якій засудили

\footnotetext{
${ }^{30}$ Kowżun P., „Petro Cholodnyj, senior”, Biuletyn Polsko-Ukraiński, 1934, R. III, 8 kwietnia, nr14 (49), s. 9.

${ }^{31}$ CAW, Od. II Sz. Gł., sygn. I.303.4.5571, k.21 (Współpraca z Ukraińcami na terenie O.K.M.).

${ }^{32}$ Ibid., sygn. I.303.4.5554, k.2 (Sekcja Ukraińska O.K.M. przy Instytucie Wschodnim w Warszawie).

${ }^{33}$ Ibid., sygn. I.303.4.5476, k.52 (Notatka w sprawie grupy “Młodonacjonalistów” przy kwartalniku "My". 24.II.1938 r.).

${ }^{34}$ CAW, Od. II Sz. Gł., sygn. I.303.4.5476, k.53 (Notatka w sprawie grupy "Młodonacjonalistów" przy kwartalniku "My". 24.II.1938 r.).
} 
ISSN 2078-6077. Наукові зошити історичного факультету Львівського університету. 2018-2019. Випуск 19-20. Proceedings of History Faculty of Lviv University. 2018-2019. Issue 19-20.

діяльність уряду УНР разом з “молодими націоналістами”. Групі “Ми” закидали звинувачення в космополітизмі й діяльності, що, на думку громадівців, була шкідливою для українського народу. У зв'язку з цим Відділ національностей МВС вносив пропозицію до уряду Польщі ліквідувати "Українську студентську громаду”, яка репрезентувала осередок українського націоналізму, й пропонував підтримати українські лояльні групи у Варшаві ${ }^{35}$.

В Експозитурі № 2 група часопису “Ми” виступала під кодовою назвою видавництва "Варяг"з6. За період від грудня 1933 р. до жовтня 1935 р. вона отримала урядових субсидій на суму 7 тис. зл., а також одноразову допомогу в сумі 500 зл. на видання двох збірок поезій.

Часопис “Ми” був удостоєний відзнаки на конкурсі української книжки у Празі, що свідчило про значні успіхи його редакції у видавничій діяльності. Однак у політичній сфері результати були незадовільні, особливо для польської сторони. Група "Ми" та ії керівник А. Крижанівський не проявляли належної активности щоб залучати студентів-українців до прометеївських акцій. Група залишилася малопомітною в середовищі української студентської молоді.

3 метою пропаганди ідей незалежної молодої думки пілсудчиків, які сповідували ідеали польського конструктивного націоналізму, було ініційоване видання двотижневика "Myśl polska" ${ }^{37}$. Дня 1 лютого 1936 р. вийшов перший номер цієї газети. Мета новоствореного часопису: актуалізувати невигідне геополітичне розташування Польщі між Німеччиною і СРСР; пропагувати прометеївську концепцію, аналізувати національні проблеми в Польщі в контексті політики державної асиміляції ${ }^{38}$. За два роки видавничої діяльности цей часопис посів провідне місце серед таких як “Pion”, “Myśl Narodowa”, "Prosto z mostu”, "Polityka".

Прометеївська ідея знаходила своїх палких прихильників не лише серед пілсудчиків, а й серед молодих національних демократів. К.-С. Фрич із газети "Myśl Narodowa" та В. Васютинський поділяли погляди пілсудчиків щодо східного питання й української справи зокрема ${ }^{39}$. К.-С. Фрич написав глибоку студію про аналогії у відродженні угорської та української нації. На думку В. Бончковського, політичне сприйняття дійсности ідеологів прометеїзму i дописів газети "Prosto z mostu" невпинно зближалося. "Kuznica" чи віленський "Paks", "ZET" чи "Polska chrobra" і багато інших молодіжних видань тією чи іншою мірою солідаризувалися 3 прометеївськими ідеями. Достатньо було проаналізувати друковані передвоєнні статті в таких часописах, як: "Prosto z

\footnotetext{
${ }^{35}$ CAW, Od. II Sz. Gł., sygn. I.303.4.5476, k.53 (Notatka w sprawie grupy "Młodonacjonalistów" przy kwartalniku "My". 24.II.1938 r.).

${ }^{36}$ Ibid., sygn. I.303.4.5471 (Kwartalnyk "My", 29.I.1937 r.).

${ }^{37}$ Ibid., sygn. I.303.4.5685, k.2 (Projekt czasopisma "Myśl polska").

${ }^{38}$ Ibid, k.3 (Notatka w sprawie wzdawnictwa dwutygodnika "Myśl polska").

39 Простір свободи. Украӥна на шпальтах паризької "Культури”, видання підготувала Б. Бердиховська, (Київ: Критика, 2005), с. 119-149.
} 
mostu”, "Kamena", “ZET”, "Przegląd Katolicki”, "Kultura Poznańska”, "Przełom”, щоб переконатися, як глибоко вкоренилися прометеївські ідеї в свідомості польської молоді ${ }^{40}$.

Влітку 1938 р. Експозитура № 2 за посередництвом редакції "Myśl polska" ініціювала порозуміння польських друкованих видань, щоб проводити спільні антикомуністичні акції. В обговоренні згаданої ініціятиви взяли участь редактори провідних ідейних видань: В. Бончковський “Myśl polska”, М. Прондзинський “Bunt Młodych”, Я. Гоппе "Jutro pracy”, В. Залеський “АВС”, Я. Габінський “Merkuriusz”, Я. Королець "Nowy Lad”, В. Пясецький “Prosto z mostu”, Я. Браун “ZET”. Окремо були проведені консультації з К.-С. Фричем - редактором газети “Myś1 Narodowa" і C. Чарнецьким - редактором газети "Przegląd Katolicki". Про подальший розвиток згаданої вище пресової акції нам, на жаль, не відомо.

Окрім зазначених методів, не виключалися й організація диверсійних молодіжних осередків. Восени 1932 р. була створена група у складі 7-ох осіб, які мали діяти на території $\mathrm{CPCP}^{41}$. Військовий еміграційний гурток молоді очолив В. Бончковський, який в документах Відділу ІІ виступав під псевдонімом "Pan Włodzimierzowski". До складу груп мали входити діти емігрантів 3 колишньої Російської імперії, які виховувалися в прометеївському дусі й прагнули активної діяльности. Створившись й організувавшись, на першому етапі грунтовно вивчали техніку конспірації, умови роботи в СРСР і ин. Одночасно вивчали літературу ідеологічного спрямування. На другому етапі вони мали опанувати різними видами зброї (пістолетом, карабіном, автоматом, гранатами, піротехнічними засобами) й транспортними засобами (машинами і мотоциклами). Причому у кожній групі мала бути принаймні одна людина - водій. На випадок війни відбувався вишкіл диверсантів, щоб здійснювати терористичні акції на території СРСР. Теоретичні приготування і практична діяльність мала відбуватися одночасно із активізацією прометеївського осередку у Львові, якому відводили роль форпосту Польщі на кордоні з СРСР.

Велику надію щодо молодого покоління мало керівництво організації “Прометей”. Очільники твердили, що молодь повинна усвідомити свою історичну місію і зрозуміти, що в недалекому майбутньому їй доведеться зайняти місце старших діячів організації і взяти на себе всю повноту відповідальности за долю своїх народів. Тому в усіх країнах планувалося організувати комітети прометеївської молоді, які б проводили систематичну роботу у формі лекцій на молодіжних форумах різних держав і тим самим здобували молодих прихильників ідеї прометеїзму. Щоб залучити до

${ }^{40}$ Zbiór dokumentów pptk. Edmunda Charaszkiewicza, opracowanie, wstęp i przypisy A. Grzywacz, M. Kwiecień, G. Mazur, (Kraków: Fundacja Centrum Dokumentacji Czynu Nipodległościowego Ksęgarnia Akademicka, 2000), s. 59.

${ }^{41}$ CAW, Od. II Sz. Gł., sygn. I.303.4.5659, k.11 (Grupa prometeuszowców czynnych. 23.II.1934 r.). 
ISSN 2078-6077. Наукові зошити історичного факультету Львівського університету. 2018-2019. Випуск 19-20. Proceedings of History Faculty of Lviv University. 2018-2019. Issue 19-20.

прометеївської акції найактивніших лідерів молодіжних організацій, пропонувалося використати особисті впливи і зв'язки ${ }^{42}$.

У жовтні 1935 р. для прометеївської молоді планували створити курси політичної пропаганди і відкрити практичний семінар, а в 1936 р. розпочати читання лекцій про організацію держави, конституцію, економіку, судочинство, військо, адміністрацію ${ }^{43}$. У планах так званого “Юного Прометея” було створити велике видавництво, яке б друкувало брошури і листівки російською мовою, призначені для молоді національних республік СРСР. Брошура мала вмістити стислий виклад ідеології прометеїзму й програму співпраці поневолених народів СРСР.

Великі надії на молодь покладало керівництво Експозитури № 2 в контексті реорганізації товариства “Прометей”, яка розпочалася напередодні Другої світової війни. Передусім слід було розв’язати проблеми щодо ідейної гармонії між молоддю і старшим поколінням прометеївської еміграції, використати потенціял молодіжного радикалізму, налагодити контакти між польською молоддю та їх ровесниками із Західної Европи. Виховання молоді відбувалося із врахуванням інтересів "Прометея" і Польщі, що для ідеологів прометеїзму фактично означало одне і теж. В. Пельц у проєкті реорганізації прометеївського руху пропонував робити ставку на молодь. Він вважав, що молодіжний радикалізм буде чинником, який найбільше мобілізує й концентрує активні сили еміграції до непримиренної боротьби з Росією, зробить неможливими компроміси з представниками еміграційних російських партій лівого напрямку ${ }^{44}$. У зв'язку 3 цим виникла необхідність модернізувати ідеологію “Прометея”. В. Пельц запропонував реорганізувати "Прометей" в Парижі, відчинивши двері для націоналістичної і радикальної прометеївської молоді, що дотепер перебувала в опозиції до національних центрів, але проявляла велику політичну активність. Роблячи ставку на молодь, організація ставила своїм завданням ії виховувати, виходячи 3 прометеївських і державних польських інтересів ${ }^{45}$.

На переконання В. Пельца, польський державний інтерес полягав у тому, щоб “Прометей” став школою виховання молоді у бойовому дусі. Необхідно було так керувати організацією, щоб об'єднати найширші маси активної молоді й здійснювати ідейний вплив на ті республіки, з яких походили емігранти. Звідси

\footnotetext{
${ }^{42}$ CAW, Od. II Sz. Gł., sygn. I.303.4.5782, k.629 ("Prometeusz" - Liga uciemieżonych przez Rosje narodów: Azerbajdżan, Don, Kubań, Gruzja, Idel-Urał, Ingria, Karelia, Komi, Krym, Kaukaz Pólnocny, Turkiestan i Ukraina. Komunikat №1, styczeń 1934 r.).

${ }^{43}$ Ibid., k.668 (Plan pracy przyjęty na posiedzeniu Zarządu Klubu "Prometeusz"w dniu 17 października 1935 r.).

44 Лев Соцков, Неизвестный сепаратизм. На службе СД и Абвера. Из секретных досье разведки, (М.:Риппол Класик, 2003), 307.

${ }^{45}$ CAW, Od. II Szt. Gł., sygn. I.303.4.5693, k.19 (L. Uwagi o kwestii reorganizacji pracy prometeuszowskiej w Paryżu.1936).
} 
мали б вербувати елементи для бойових організацій, створення яких передбачалося в інших документах ${ }^{46}$.

Отже, виховання молоді в Польщі на ідеалах великодержавности стало складовою частиною прометеївської діяльності. Основна увага зверталася на виховання польської молоді, а також молодої еміграції з Російської імперії. Для них виховним ідеалом став особистий приклад Ю. Пілсудського. Мета виховання - готувати молодь втілювати в життя ідеали прометеїзму, що полягали у відродженні Великої Польщі. Основним осередком вишколу молодих прометеїстів став Східний Інститут, на базі якого створено Орієнталістичний гурток молоді. Для багатьох осіб він став школою виховання польського патріотизму й відданости ідеалам Ю. Пілсудського. Емігрантську молодь залучили також за рахунок стипендіяльних акцій. Найрадикальнішу молодь зорганізовано у військові гуртки, діяльність яких мала бути перенесена на територію СРСР.

\title{
YOUTH POLICY IN SANATION POLAND in 1930s
}

\author{
Volodymyr KOMAR \\ The Vasyl Stefanyk Precarpathian National University \\ Department of Slavic History \\ Shevchenko str. 57, 76025, Ivano-Frankivsk, Ukraine \\ e-mail: wolodymyr.komar@gmail.com
}

The article analyzes the formation of youth policy in the context of the implementation of the Prometheism concept of interwar Poland. These ideas were shared by the colleagues of Y. Pilsudski, grouped in the company of "Prometheus" and the so-called Promethean movement. The anti-Russian and anti-communist orientation of the concept was aimed at the collapse of the Soviet Union and the construction on its national outskirts of independent states, united in the federation with Poland. The main idea of the article is that Polish and emigrant youth in Poland were given a key role in implementing this policy.

The phenomenal ability of Marshal Y. Pilsudski to unite talented people was manifested in the organization of the Promethean Front of Peoples, who found support for certain figures of the state apparatus of power. The attention of the most influential man in the Polish state to the representatives of the people who fought for independence, had for them also great moral and political significance.

The concept of Poland's prometheism became relevant after the May 1926 coup and the coming to power of the Sanation regime. Its foreign policy vector was aimed at the collapse of the Soviet Union with the prospect of the formation of independent states under the auspices of Poland. Convinced of the short-lived existence of a new type of multinational Soviet empire, supporters of Prometheism from the Y. Pilsudsky camp sought to bring in the orbit of their political influences non-Russian peoples through the creation of separate national states from the Baltic to the Black Seas (Ukraine,

${ }^{46}$ CAW, Od. II Szt. G1., sygn. I.303.4.5693, k.8 (Forma organizacyjna.1936). 
ISSN 2078-6077. Наукові зошити історичного факультету Львівського університету. 2018-2019. Випуск 19-20. Proceedings of History Faculty of Lviv University. 2018-2019. Issue 19-20.

Georgia, Azerbaijan, Crimea, and others) and subordinate them to Poland on the basis of federal ties. To implement this concept, it was necessary to educate young people, not only Polish, but also from the emigration environment. The leading role was assigned to the Eastern Institute (EI). In its activity, the main role was assigned to the Ukrainian issue, which emphasizes the relevance of the chosen theme for domestic politics and science.

Y. Pilsudski, whom the Polish people owed their state existence, said: "Work for the good of the fatherland is our goal and duty!". These words set the direction in the upbringing of youth and Polish young people, inspired by them, put forward plans to combat the Soviet totalitarian system. The life of Pilsudski was a pattern of imitation for them. In addition, Y. Pilsudsky's nationalism was marked by realism. He rejected all sorts of party interests, all kinds of unnecessary discussions about the social principles that scattered forces, and concentrated efforts in one direction. Pilsudski's perception of political realism also helped to establish a constructive dialogue between senior Promethean generations and young people and created conditions for mutual cooperation. Huge reliance was on Polish youth, as well as on the younger generation in the environment of emigrants from Russia, especially Ukrainians. They had to work together with the Poles to create Great Poland, which was the ultimate goal in implementing the concept of Prometheism.

Thus, the education of the younger generation of Poland concerning the ideals of the great power became an integral part of Promethean activity. The main focus was on the education of Polish youth, as well as young immigrants from the Russian Empire. For them a personal example of Pilsudski became the educational ideal. The purpose of education was to prepare young people for the realization of the ideals of Prometheism, which consisted of the revival of Great Poland. The main center for the training of young prometheists was the Eastern Institute, on the basis of which they created the Orientalist Youth Circle. For many generations it became a school for the education of Polish patriotism and loyalty to the ideals of Y. Pilsudski. Engagement of immigrant youth was also due to scholarships. The most radical youth was organized in military circles, whose activities were to be transferred to the USSR.

Keywords: Pilsudski, Holuvko, Bonchkovsky, Prometheism, Eastern Institute.

\section{REFERENCES}

Abdank-Kossovsky, Venedikt. "Chud redistribution of Russia”, Revival, № 2592, (1932), p. 2. (in Russian);

Biblioteka Polska w Paryżu, Akta Władysława Pelca, sygn. 1156/I, k.72 (Notatka dla Pana Ministra Jędrzejewicza "Nastroje polityczne młodzieży akademickiej”) (in Polish);

Biblioteka Polska w Paryżu, Akta Władysława Pelca, sygn. 1136, k.55 zw. (Wypis z aktu notarialnego powołującego Fundacje stypendialną im. Śp. Tadeusza Hołówki) (in Polish);

Central State Archives of Supreme Bodies of Power and Government of Ukraine, Fond 3532, Series 1, File 11, Sheet 6 (Correspondence of the students of the institute with the Holovko Scholarship Committee in Warsaw on the allocation of scholarships to students of the Institute. 28.10.1937-28.12.1938) (in Ukrainian);

Centralne Archiwum Wojskowe, Oddział II Sztabu Głównego, sygn. I.303.4.5405 (Korespondencja w sprawie przyznawania stypendijów, kwestionariusze stypendystów narodowośći tatarskiej tatarskiej, 1927-1937) (in Polish);

Centralne Archiwum Wojskowe, Oddział II Sztabu Głównego, sygn. I.303.4.5405, k.17 (Przyjęcie stypendysty-studenta od r.1934-1935). Ibid., k.25 (Stypendysta Idel-uralski. 1.X.1937 r.) (in Polish);

Centralne Archiwum Wojskowe, Oddział II Sztabu Głównego, sygn. I.303.4.5471 (Kwartalnyk "My", 29.I.1937 r.) (in Polish); 
ISSN 2078-6077. Наукові зошити історичного факультету Львівського університету. 2018-2019. Випуск 19-20. Proceedings of History Faculty of Lviv University. 2018-2019. Issue 19-20.

Centralne Archiwum Wojskowe, Oddział II Sztabu Głównego, sygn. I.303.4.5476, k.52 (Notatka w sprawie grupy “Młodonacjonalistów” przy kwartalniku "My”. 24.II.1938 r.) (in Polish);

Centralne Archiwum Wojskowe, Oddział II Sztabu Głównego, sygn. I.303.4.5476, k.53 (Notatka w sprawie grupy “Młodonacjonalistów” przy kwartalniku "My”. 24.II.1938 r.) (in Polish);

Centralne Archiwum Wojskowe, Oddział II Sztabu Głównego, sygn. I.303.4.5502, k.16 (Stypendisci Turkiestańczycy. 4 listopada 1936 r.) (in Polish);

Centralne Archiwum Wojskowe, Oddział II Sztabu Głównego, sygn. I.303.4.5507, k.4 (Podział stypendijów ukraińskich w r. 1934-1935 przez Ukr. Inst. Nauk. 11.II.1935 r.) (in Polish);

Centralne Archiwum Wojskowe, Oddział II Sztabu Głównego, sygn. I.303.4.5516, k.5 (OKM przy Instytucie Wschodnim w Warszawie - charakterystyka, 2.III.1931) (in Polish);

Centralne Archiwum Wojskowe, Oddział II Sztabu Głównego, sygn. I.303.4.5554, k.2 (Sekcja Ukraińska O.K.M. przy Instytucie Wschodnim w Warszawie) (in Polish);

Centralne Archiwum Wojskowe, Oddział II Sztabu Głównego, sygn.I.303.4.5554, k.2 (Prezydium Pierwszego zjazdu Orijentalistycznych Kół Młodych w Warszawie. 3.VIII.1932 r.) (in Polish);

Centralne Archiwum Wojskowe, Oddział II Sztabu Głównego, sygn. I.303.4.5554, k.2 (Orijentalistycznå Koło Młodych. IV.1931 r.) (in Polish);

Centralne Archiwum Wojskowe, Oddział II Sztabu Głównego, sygn. I.303.4.5554, k.7 (Rzut oka na historję O.K.M.) (in Polish);

CentralneArchiwum Wojskowe, Oddział II Sztabu Głównego, sygn. I.303.4.5554, k.22 (in Polish);

Centralne Archiwum Wojskowe, Oddział II Sztabu Głównego, sygn. I.303.4.5571, k.2 (Stypendysci Górale Kaukascy) (in Polish);

Centralne Archiwum Wojskowe, Oddział II Sztabu Głównego, sygn. I.303.4.5571, k.21 (Współpraca z Ukraińcami na terenie O.K.M.) (in Polish);

Centralne Archiwum Wojskowe, Oddział II Sztabu Głównego, sygn. I.303.4.5772, k.42 (Stypendysci azerbejdźańcy - postępy w nauce i ocena wartości ideowej. 1932 r.) (in Polish);

Centralne Archiwum Wojskowe, Oddział II Sztabu Głównego, sygn. I.303.4.5571, k.47 (P. Wice Dyrektor Departamentu Politycznego i Naczelnik Wydziału Wschodniego MSZ ) (in Polish);

Centralne Archiwum Wojskowe, Oddział II Sztabu Głównego, sygn. I.303.4.5659, k.11 (Grupa prometeuszowców czynnych. 23.II.1934 r.) (in Polish);

Centralne Archiwum Wojskowe, Oddział II Sztabu Głównego, sygn. I.303.4.5668, k.12 (Informacja o rozliczenia stypendiow przeslany przez placuwke "Milton” w Paryzu. 1937 r.) (in Polish);

Centralne Archiwum Wojskowe, Oddział II Sztabu Głównego, sygn. I.303.4.5672, k.20 (Stypendium studenckie Natalii Zordanii na studiach w Paryżu. 12.IV.1937 r.) (in Polish);

Centralne Archiwum Wojskowe, Oddział II Sztabu Głównego, sygn. I.303.4.5685, k.2 (Projekt czasopisma "Myśl polska") (in Polish);

Centralne Archiwum Wojskowe, Oddział II Sztabu Głównego, sygn. I.303.4.5685, k.3 (Notatka w sprawie wzdawnictwa dwutygodnika "Myśl polska") (in Polish);

Centralne Archiwum Wojskowe, Oddział II Sztabu Głównego, sygn. I.303.4.5693, k.8 (Forma organizacyjna.1936) (in Polish);

Centralne Archiwum Wojskowe, Oddział II Sztabu Głównego, sygn. I.303.4.5693, k.19 (L. Uwagi o kwestii reorganizacji pracy prometeuszowskiej w Paryżu. 1936) (in Polish);

Centralne Archiwum Wojskowe, Oddział II Sztabu Głównego, sygn. I.303.4.5693, k.28 (L. Uwagi o kwestii reorganizacji pracy prometeuszowskiej w Paryżu. 1936) (in Polish); 
ISSN 2078-6077. Наукові зошити історичного факультету Львівського університету. 2018-2019. Випуск 19-20. Proceedings of History Faculty of Lviv University. 2018-2019. Issue 19-20.

Centralne Archiwum Wojskowe, Oddział II Sztabu Głównego, sygn. I.303.4.5701, k.1 (O.K.M. przy Instytucie Wschodnim w Warszawie) (in Polish);

Centralne Archiwum Wojskowe, Oddział II Sztabu Głównego, sygn. I.303.4.5701, k.1 (Wycieczka O.K.Mu. do Bułgarii w czasie od 3.VIII. do 30.VIII.1936 r. (in Polish);

Centralne Archiwum Wojskowe, Oddział II Sztabu Głównego, sygn. I.303.4.5701, k.1zw. (Deklaracja O.K.M. - odpowiedź na depesze MARTINA. 17.VIII.1932 r.) (in Polish);

Centralne Archiwum Wojskowe, Oddział II Sztabu Głównego, sygn. I.303.4.5701, k. 1zw. (Wycieczka naukowa Członków O.K.M. przy Instytucie Wschodnim w lecie 1936 r. na Bliski Wschód. 15.VII.1936r.) (in Polish);

Centralne Archiwum Wojskowe, Oddział II Sztabu Głównego, sygn. I.303.4.5701, k.2 (O.K.M. przy Instytucie Wschodnim w Warszawie) (in Polish);

Centralne Archiwum Wojskowe, Oddział II Sztabu Głównego, sygn. I.303.4.5782, k.627 ("Prometeusz" - Liga uciemieżonych przez Rosje narodów: Azerbajdżan, Don, Kubań, Gruzja, Idel-Urał, Ingria, Karelia, Komi, Krym, Kaukaz Pólnocny, Turkiestan i Ukraina. Komunikat №1, styczeń 1934 r.) (in Polish);

Centralne Archiwum Wojskowe, Oddział II Sztabu Głównego, sygn. I.303.4.5782, k.629 ("Prometeusz" - Liga uciemieżonych przez Rosje narodów: Azerbajdżan, Don, Kubań, Gruzja, Idel-Urał, Ingria, Karelia, Komi, Krym, Kaukaz Pólnocny, Turkiestan i Ukraina. Komunikat №1, styczeń 1934 r.) (in Polish);

Centralne Archiwum Wojskowe, Oddział II Sztabu Głównego, sygn. I.303.4.5782, k.668 (Plan pracy przyjęty na posiedzeniu Zarządu Klubu "Prometeusz" w dniu 17 października 1935 r.) (in Polish);

Kowżun P., "Petro Cholodnyj, senior”, Biuletyn Polsko-Ukraiński, 1934, R. III, 8 kwietnia, nr 14 (49), s. 9 (in Polish);

Russian State Military Archive, Fond 461/k, Series 1, File.1, Sheet 161 (Orjentalistyczne Koło Młodych przy Instytucie Wschodnim w Warszawie) (in Polish);

Sotskov L.F. An unknown separatism. On service of the SD and Abwehr. From secret files of the intelligence service. - M.: Ripol Classic, 2003. - p. 336 (in Russian);

Space of freedom. Ukraine on the pages of Parisian "Culture". The publication was prepared by Bohumila Berdychovska. - Kyiv: Criticism, 2005. - p.119-149 (in Ukrainian);

Zbiór dokumentów ppłk. Edmunda Charaszkiewicza. Opracowanie, wstęp i przypisy A. Grzywacz, M. Kwiecień, G. Mazur. - Kraków: Fundacja Centrum Dokumentacji Czynu Nipodległościowego Ksęgarnia Akademicka, 2000. - 185 s. (in Polish);

“Z życia Orjentalistycznego Koła Młodych”, Wschód-Orient, 1930, nr 1, s. 31 (in Polish);

“Ż̇ycia Orjentalistycznego Koła Młodych w Warszawie”, Wschód-Orient, Październik 1932 maj 1933, R.IV, nr 1-2 (9-10), s. 99. (in Polish);

“Z życia Orjentalistycznego Koła Młodych w Warszawie” , Wschód-Orient, Styczeń 1932, r. III, nr 1-2(5-6), s. 90 (in Polish). 